\title{
Conjuring the Ghost: A Call and Response to Haints
}

\author{
drea brown \\ Department of English, Texas State University, San Marcos, Texas, USA \\ Corresponding author. E-mail: drea.brown@txstate.edu
}

(Received 1 August 2019; revised 14 August 2020; accepted 15 March 2021;

first published online 24 September 2021)

\begin{abstract}
This article discusses haunting as a condition and strategy for Black women in their lived and literary experiences. I use the haint as a key figure for understanding Black women's liminal state as both the ones haunted and the thing haunting and focus on one of the haint's primary manifestations: the hag. Throughout the essay I unpack maligning myths of this specter and center the works of Phillis Wheatley and Lucille Clifton to refigure the hag as a spiritual and ancestral presence.
\end{abstract}

I should begin with a confession: I believe in ghosts. Shadows caught slinking in a dim hallway, night terrors on repeat, screams echoing in a church-house decked for hallows eve, closets that push or pull you in. I remember bleeding and believing it a blessing. Every time I am dragged to the back pew of the sanctuary, a cold hand grips my shoulder, fingers impossible and familiar. But no one is there, only the chill and curious eyes of ushers. After my friend's child is killed, I dream her pregnant, the baby stillborn. She kisses its cold face, rocks, and names him, says this will bring him back to life. I wake mouth open to sound him out. I know how Sweetie Pie knew the plantation on which she was born but could not remember her mother's name. Only sometimes how she looked. Smelled. Am I asleep or awake when I fight my father's smirk and pickled eyes? Does this matter? Either way he is here. Each autumn since my grandmother's passing the same cardinal comes to her bedroom window, tucks beneath the awning, watches my mama sleep every night until spring. There are many kinds of ghosts.

This essay aims to delineate my practice of this belief. In this exploration I uncover routes of knowing, ways of conjuring ghosts and what must be done in their presence. Such invoking requires journeying between worlds known and unknown where something familiar may suddenly appear unusual and changed. Such is the case with ghosts, wonted and estranged in their clamor and coming back, again and again. Throughout, I lean into Black feminist theorizations and literary possibilities to map relationships between flesh and shadow and what lurks in the shade. I begin by lifting the veil of $\mathrm{Du}$ Bois, seeking what lies in the dark, the way Blackness begets a haunted people. I

(C) The Author(s), 2021. Published by Cambridge University Press on behalf of Hypatia, a Nonprofit Corporation. This is an Open Access article, distributed under the terms of the Creative Commons Attribution licence (http://creativecommons.org/licenses/by/4.0/), which permits unrestricted re-use, distribution, and reproduction in any medium, provided the original work is properly cited. 
then turn to ghost stories, the many ways haunting manifests and serves as epistemology and experience for Black women. I look to the effigy of haints, what is signified through their presence, and bring the hag into view. The hag becomes a guiding force who leads us into the poems of Lucille Clifton and Phillis Wheatley, who bears witness to what breathes there, how a body is transformed from subject to object and then to some thing bound between. I will show you how the hag keeps us alive. To do this I wade through the murk to investigate the mark left in her wake. In this essay I name the hag as an ancestral and spiritual presence whose call demands our response. Together we go to the place where she dwells, to hear her out, to take her in. By this journey's end I return "home" to the watery terrain of promise and demise, waves and waves of loss and what is found-mercy in the arms of the ever-present spectral. But let us begin with the veil, with ways of seeing and being in a space teeming with ghosts.

\section{The Haunted Souls of Black Folks}

It dawned upon me with a certain suddenness that I was different from the others . . . but shut out from their world by a vast veil. I had thereafter no desire to tear down that veil, to creep through. ...

-W. E. B. Du Bois, The Souls of Black Folk

Du Bois begins this rumination by examining an unasked question: "how does it feel to be a problem?," the posture of which doubles as an accusation that Blackness is problematic, and not "the other world" that undermines it (Du Bois 1903, 1). That to be Black in America is to be some thing instead of someone, a suddenness of difference. How does that feel? That what we be is determined outside of ourselves, is a problem. That we should feel what we be, "shut out from the world by a vast veil," is another. Veils prohibit recognition, they produce a blur, a penumbra that alters the way we see and are seen. They lead to what Du Bois terms double consciousness, "this sense of always looking at one's self through the eyes of others, of measuring one's soul by the tape of a world that looks on in amused contempt and pity. One ever feels his twoness-an American, a Negro; two souls, two thoughts, two unreconciled strivings; two warring ideals in one dark body" (3). This duality of living beneath the veil produces a kind of haunting, what Marisa Parham views as "a sense of what it means to live in between things - in between cultures, in between times, in between spaces-to live with various kinds of double consciousness" (Parham 2008, 3). To be a problem, to be shut out by the veil, is a strange and uncanny thing. For Du Bois the veil is a figurative division, a sign of repression and structural racism. But, beneath the veil, Black folk survive, our haunted souls endure. Haunting is what festers in the aftermath of slavery and the indelible echoes that follow. Consider legacies of our making, trade and trickery, stashed commodities, the relentless lash of ancestors' tongues, and yowling spirits-all that has been suppressed, what brands, injures, aims to erase our bodies, memories, histories. Haunting is that "merging of the visible and the invisible, the dead and the living, the past and the present-into the making of worldly relations and into the making of our accounts of the world. It is a case of the difference it makes to start with the marginal, with what we normally exclude or banish, or, more commonly, with what we never even notice" (Gordon 1997, 24-25). I know this to be true: we are a haunted people.

Veils enable us to grieve a disposition in a world that refuses to see-leaving dark bodies simultaneously invisible and hypervisible, but never quite fully here or there. With "no desire to tear down that veil, to creep through," haunting serves as a strategy 
for navigating "other worlds" and in turn our own ghostliness. So how does it feel, what does it look like to live with ghosts? To be a "swarthy spectre sit [ting] in its accustomed seat" (Du Bois 1903, 4)? Such apparitional allusions cause me to consider my place, what it looks like to be Black and woman entangled with a such a history, haunted by the very things that spit you out. Ghosts are restless and take hold of the veil. There is no denying the power of such things moving margin to center, disrupting boundaries and expectation. Ghosts trouble dominant narratives, they straddle worlds of consciousness and visibility; proof that "invisible things are not necessarily 'not there," that the dead do not rest easy, that problems push back (Morrison 1989, 136). A door opens that was not there before, a voice calls, a hand grips and will not let go, something wakes in need. Ghosts serve as testament, a refusal to be disappeared. Like Hershini Bhana Young, I am interested in how haunting leads to epistemologies "fundamentally concerned with redress, with honoring the cultural and spiritual memories of colonized people" (Young 2006, 31). I want to go into stories of the veil, into liminal spaces to explore how haunting enables a reimagining of subjectivity.

\section{Haunting Origins}

The earliest etymology of the phrase "to haunt" can be traced to twelfth-century Norse and proto-Germanic origins, meaning to go or bring home; to thirteenth-century France, where "to haunt" implied frequency and familiarity, regular visitation, to indulge and take part. The first example of haunting in our contemporary understanding comes from those enslaved during the antebellum period, referencing a "spirit that haunts a place, a ghost" (Online Etymology Dictionary n.d.). Thus, haunting denotes a return, frequency, and familiarity, a bringing (spirit) back or returning to, but where? Home, for many Black folks, is a loaded concept. Going home is a crossroads inhabited by lives and afterlives, a free and fettered space that feels (im)possible and full of promise, that must be confronted in order to move through. It is the low hum of spirituals and codified melodies where going home, or home-going, means freedom, or death, or finding freedom in death and a heavenly by and by. By all accounts, home and haunting bring me back or take me to water, to passage and trans-Atlantic crossings. It is the Igbo who, rather than be enslaved in a "new world," hurled themselves into the Atlantic, to walk home. For so many disposed of and dispossessed, perhaps water is the closest thing to kin and country. Because Blackness has been fed by so much loss, lost at sea, vanished in the veil, we return almost obsessively, for closure, opening, or suture.

Haunting is inevitable. It brings other ways of knowing, routes of going; for Black folk it is not so much a return to a geographical place, but a return to being. "A spirit that haunts a place-a ghost" wants to go or be brought back, to return home. Ghosts lead us beneath and in between; they are in this sense conceived beyond logic and into realms of the otherworldly and spiritual. This notion of the spiritual, as Judylyn Ryan defines it, is not tied to any one religion but instead several traditions within African cultures which "include the belief in God, belief in divinities and other spirits, belief in the sustaining presence of ancestors, and belief in the practice of magic" (Ryan 2005, 23). To understand ghosts as the presence of spirit suggests that though haunting is the result of festered injury, it is not devoid of the sacred. It calls for a return to the scene of the crime, a return of the spirit to an (individual and collective) self. This means ghosts hold past, present, and future all at once, the living and the dead. Ghosts are sordid and supreme. 
As such we must take seriously Hortense Spillers's assertion that slavery transformed Black women into "the principal point of passage between the human and non-human world," and that liminal state persists (Spillers 2003a, 155). Black women are both the ones haunted and the things haunting, a position I liken to the haint. The term haint, a vernacular derivative of haunt, can be traced to the Gullah people of South Carolina. It refers to a disruptive spirit, an unruly, enraged, and ornery ghost-generally a woman. If the haint is also haunted, then her rage is not without root or lingering ailment, inseparable from our lived experience. In Ghosts in Popular Culture and Legend, June Michele Pulliam and Anthony J. Fonseca note that Southern folklore "liken[s] the haint to various types of ghosts, including the revenging revenant, the hag, and the banshee, and the manifestation can range from a clear definable human spirit (which can be a shadow, a luminescent figure, or a transparent human shape) to an undefinable entity with no human qualities" (Pulliam and Fonseca 2016, 143). I view her in her many forms steadily as Black (given the origin), and woman, given that women (particularly Black women) are stereotypically referred to as vengeful when angered, hags when old, unmarried, or eccentric, banshees when loud or wailing. But I do not read the haint as malicious; I believe she is mis-taken, and unheard. Like haints, Black women are often relegated to frightening caricatures. The descriptions above are eerily close to those of Jezebel (the oversexed and vengeful), Sapphire (the all-up-in-your-face banshee), and Mammy (the asexual hag). Unlike Jezebel and Sapphire, Mammy is a powerful trope precisely because she is "unseen"; her anger is unanticipated because of an assumed contentment. But what if we peel back her satisfied smile to encounter her madness only to find her enraged and "unruly." This Mammy is demonstrated in Betye Saar's artwork The Liberation of Aunt Jemima (1972), made visible and visceral not through her gleaming pearly whites, but the gleam of guns she keeps closer than broom, by the contrast of the barely brown child in her arms, mouth agape to the horror of it all, the black fist protruding glaringly from her skirt. She is found in the 2019 popular film $\mathrm{Ma}$ where Octavia Spencer strongarms the stereotype, feeding and exploding years (or centuries) of pent-up rage, released as what feels like nothing less than Mammy's revenge. This controlling image continues to haunt our contemporary landscapes. Alongside an assemblage of others, I name her a hag, a foremother whose echoing screams incessantly prod Black women. So much is done to quiet her call it is difficult to see that this haint-the hag, like Black women-may be longing for something to be done.

\section{Conjuration: Hags in Black Women's Poetry}

As a means of further fleshing out this figure, I turn to the poetic, because it enables us to access the uncanny; in fact, we expect it. Poetry lies beyond the sense of the head and in the emotion of the heart. It is a deepening of thought into the body, and as Audre Lorde theorizes, that "dark place within, where hidden and growing our true spirit rises" (Lorde 1984, 36). It is through this place that poetry provides access to a deep reserve of power through which we can name ourselves, the worlds around us. Poetry is, quite simply, spirit work. It requires a willingness to go there-to that place of memory, $\mathrm{im} /$ possibility, to that space beyond fleshly understanding. It is poetry that serves as a connector between this world and another that exists before and beyond our individual lives. I turn to the poetic because in this context of haunting, it is a tool of theorizing. As Barbara Christian notes, "our theorizing (and I intentionally use the verb rather than the noun) is often in narrative forms, in the stories we create, in riddles and 
proverbs, in the play with language, because dynamic rather than fixed ideas seem more to our liking ... how else have we managed to survive with such spiritedness the assault on our bodies, social institutions, countries, our very humanity" (Christian 1987, 68)? I view this as exceptionally so for Black women. Persisting in the face of motley assaults requires a constant need to do-to reimagine, strategize, theorize; it requires self-making and passing this work on. I consider a significant part of this doing to be the act of surviving with "spiritedness." Such survival suggests an unremitting desire to be alive, to be courageous, to be full of or fortified by spirit(s). The subtext, then, is that it is this spiritedness that enhances the quality of life, that it is in relationship with said spirit that Black women dare to live. Living with spiritedness is an inherent aspect of Black women's subjectivity - what it means to live beneath the veil. It is the spiritedness of Black women's poetry that also frames my methodological approach, what I call textual mediumship.

There are many channels of mediumship: Ouija boards, tarot cards, palms, tea leaves, coffee grounds, water. Each is a method of communicating with worlds beyond the surface of our knowing. Each one requires diligence and set intention, guidelines and instruction, a specific way of working. Say the poem is a haunted house and this methodology a conjuration that brings out the ghosts. Textual mediumship allows for question, call, and response: is there a spirit who wants to speak, something that needs to be seen so it can be named? It requires a close reading that privileges dyads of presence and absence, image and shadow, sound and echo. It is reading a written line and hearing the one unspoken, refocusing the lens to bring haints clearly into view. Black women's poetry is often fertile ground for textual mediumship because so much troubles the lines; something hidden or indirect needs unmasking, time seems to collapse, space comes into question. The poems may be polyphonic, or have an ambiguous "I," something unsettled, plural, or choral. This heightens what Mae Henderson deems distinctive about the interlocutory nature of Black women's writing that reflects "not only a relationship with the 'other(s)' but also an internal dialogue with the plural aspects of self that constitute the matrix of black female subjectivity" (Henderson 2014, 60). Because we are a haunted people, because we survive with spiritedness, I offer that these internal conversations may also be representative of dialogues with the spectral. As Katherine Bassard asserts, "it is within this divine dialogue that Black women's subjectivity is produced, even as her agency is acknowledged and affirmed" (Bassard 1999, 3). The poems in this essay-Lucille Clifton's "shadows" and Phillis Wheatley's "On Being Brought from Africa to America"-fall into these categories, as does much of their work. Clifton's later poems, described as messages received from "the Ones," and Wheatley's recurring appeal to mythological and spiritual figures, are indications of how Black women exist inseparably from spirits and spiritedness. Perhaps we could call textual mediumship a kind of séance, the poem a conduit to the specter-world. If spiritedness fills us and wills us toward survival, then haints-hags-are a resource, an archive, something that has already been. Something before, and between and after (lives).

Clifton's poetry hovers in the between-she revels in ancestry while lamenting a lost history, marvels in the inherited magic of "having been born, like her mother and one of her daughters, with six fingers on each hand, and being baffled and outraged by the constant barrage of suffering she endured" (Davis 2013). Clifton is no stranger to haunting, and ancestral ghosts often seethe beneath the succinctness of her sharp lines. The poem "shadows" is divination, a message that foretells a coming to one place while standing in the shadows of another. It is there we find the haint, an 
unraveling voice that lifts the veil and reaches out. The title implies an inherited connection, a real image appeared and inextricable from its host, a body shrouded by loss, by forgetfulness, that makes itself known in the light. What waits there is not something other but instead "another," another place, another time, another body of water, another woman-ancient, and wanting to be seen, and carried forward.

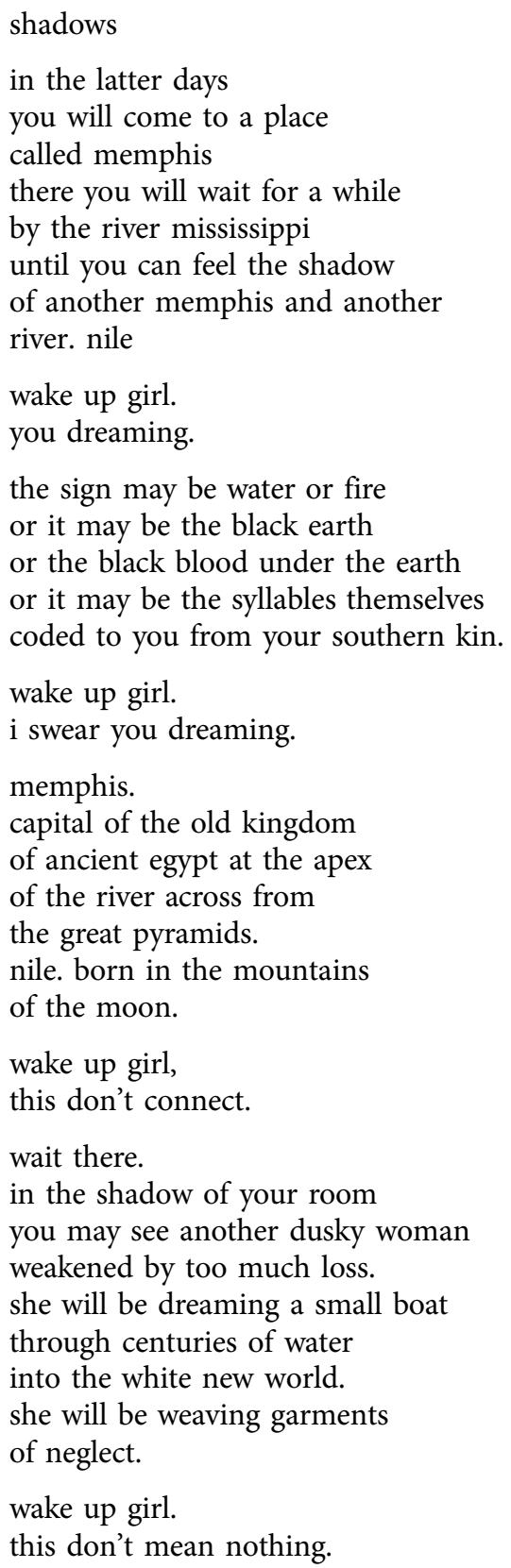


meaning is the river

of voices. meaning

is the patience of the moon.

meaning is the thread

running forever in shadow.

girl girl wake up.

somebody calling you. (Clifton 2012, 501-2)

Time fades in "shadows," the present is a dream of future, the future an opening to a past in need of remembering. The poem is slender and moves steadily through white space like another "small boat/through centuries of water" (lines 31-32). As each sharp line opens to the next, the poem, as shadows do, seems to spread across the page, leaving nothing untouched. Even when the page breaks, shadows continue to entrance. " Throughout the poem shadows instruct, a persistent "river of voices" (lines 38-39) intent on delivering messages and signs to a "you" whose journey leads toward a deeper connection with what and who comes before. They reveal a doubling of landscapes-places, names, memories - to show that as we come to one place, we will "feel the shadow of another" (lines 6-7). Their insistence suggests that ghosts make themselves known in myriad ways. They are, as Arthur Redding notes, "persistent, and beckoning-specters, absences that refuse to absent themselves" (Redding 2001, 176). They show themselves as light, as timeworn, they bring signs through the elements, "water or fire/or it may be the black earth" (lines 11-12). The signs of their existence already in the body and the "black blood under the earth" (line 13). Even the tongue holds ghosts "coded to you from your southern kin" (line 15). Here, the ancestral is place, space, and persons. Throughout the piece, shadows demand our attention despite suppression and attempted erasure. Shadows, like haints, suggest that we are not alone; there is always something and someone already here "and there" in the looming shapes between dark and light.

Between each stanza is a shifty, two-line refrain. This nagging and continuous poke magnifies the tension between what shadows bring and wanting to acknowledge it. Each repeated "wake up girl" tries to coax "you" from an in-between space called dream. The lucid images in each refrain call out, "you dreaming." "I swear you dreaming" (line 10), "this don't connect" (line 17), "this don't mean nothing" (line 26), but we are awake, and it does, it does. This repetition is integral to the structure of the poem and to the strategies of the haunt, how it circles back and resonates across pages. This disruptive voice repeats, this another and another unfurls, these signs appear again and again. Here is the tension between the beauty and terror of haunting, that despite resistance, shadows do not go away. This is how haunting feels, as if worlds have collided so fully that it is disorienting, almost unbelievable, then a voice pokes from inside and out, casting doubt or question. And yet, every stanza that follows the refrain become more potent with the urgency of connecting with shadow. We are instructed to stand in shadow, to wait while the moon that births rivers brings "another dusky woman/weakened by too much loss" (lines 29-30). As the poet dreams, as Black women dream, there is another Black woman, dreaming "a small boat/through centuries of water" (lines 3132). In shadows the haint functions as an ancestral presence, this before-mother "weaving garments/of neglect" (lines 34-35). As Mary Jane Lupton notes, this is "presumably the poet's great-great-grandmother Caroline" (Lupton 2006, 52), the Dahomey ancestral 
presence in Clifton's memoir Generations, one the poet frequently returns to as she works to move through a history of loss and what is left behind.

In this haint's desire to be seen, water incessantly floods the page. Water, troubled as it may be, is also a sacred space with the power to swaddle and restore, to hide and set free. The opening lyrics of that old Negro spiritual "Take Me to the Water" express a need for renewal or recovery of the spirit, a cleansing rite of passage that saves a soul instead of thieving it: "take me to the water, take me to the water, take me to the water, to be baptized" (lines 1-4), fills a body with the holy ghost. By some doctrines, one cannot "go home" without it. "Wade in the Water" is another example of this. In this spiritual, it is the soaking, what is possible when we are fully immersed. "Wade in the water children" (line 2) for a signal to move, for somebody to call. The presence of this dusky woman reflects the haunting and haunted nature of Black women, in need of tending, dreaming of mobility, of moving through loss, for centuries. She is an invitation to wade trusting - "Gods a-going to trouble the water" (line 3)-that something divine will intervene and wave a hand to change the current. Even though the poem's refrain maintains "this don't mean nothing" (line 37), there is the unshakable message that it does, that it must. Clifton's poem is a reminder that sometimes, all that can be done with shadows-with haints-is to face them. It is, after all, reckoning with the spectral that recovers what has been suppressed, that finds meaning "is the river of voices. /meaning is the patience of the moon. meaning is the thread/running forever in shadow" (lines 38-42). Endless and ancestral, meaning is a call, in need of response. "Wake up girl," the poem insists.

Hags, Witches, and Mammies, an Ancestral Presence

$$
\begin{array}{r}
\text { maybe it is the afrikan in me } \\
\text { still trying to get home } \\
\text { after all these years } \\
\text {-Lucille Clifton, "hag riding" }
\end{array}
$$

I say the haint in Clifton's poem "shadows" is a hag, an elder who has the right of way. She is a point of entry to lived experience, an ancestral presence integral to Black womanhood, reimagined beneath the veil, invoked in a passage of betweenness. In her desire to return home, she speaks alongside what is made blurry or invisible, the anothers that come before and stay and wait, realized through dream and vision, through waking, through writing, through veneration of their spiritedness. Folktales and myths of the hag suggest the kind that shuffle-steps slowly due to some curious limp. Isolated, living deep in a wooded area or the outskirts of town off one dirt road on to another. Pushed out or tucked away like secret, she comes when taunted or beckoned, or comes with purpose to retrieve some lost or forgotten thing. She is often presumed to be not just old, but ugly, someone to keep away, something unacceptable and unpleasant. She exudes a kind of negative sexuality, or none at all. The hag is generally wizened, the keeper of some bit of information, some secret knowledge that ensures her eccentricity or some mystical association. Duplicitous in fairy and folktales, tempting children with poisoned apples, snapping them like candy-sticks. Think swamp-dwellers with tinctures ripened by moonlight, bags of rattling bones, clouded eyes that see dim futures, a boiling pot of carrot tops and fingertips. 
“The hags, those 'weird sisters' in Macbeth, are repulsive old women with supernatural powers. In a subtle way they can foretell the future, and they have the power to torment those with whom they come into contact" (Ross 1980, 183). In some tales, they "are living people who ride their victims while the victims are asleep. They may even suck blood from their victims. A few people hold the belief that hags slip off their skins while they ride their victims" (183). In others, the hag is a shapeshifter, the old woman her primary cloak-skin. As Kinitra Brooks states, "the Boo Hag is a monster from the Gullah folklore that features a skinless woman who borrows the skin of others until she has absorbed their entire essence" (Brooks 2018, 128). Hags portrayed as thieves stealing children, blood, and lives instill an almost irreparable fear. Their exile seems necessary for our safety. The hag may also be called a witch, a term dangerously used in early America and even now to persecute women's difference, though counter-narratives work to reposition her. As Luisah Teish argues, "Instead of the evil, dried-out, old prude of patriarchal lore, we know the witch to be a strong, proud woman, wise in the ways of natural medicine. We know her as a self-confident freedom fighter... . We know that she was slandered, oppressed and burned alive for her wisdom and her defiance of patriarchal rule" (Teish 1985, ix). Teish calls for a disinheritance of narrow views that obstruct our perceptions of these women, and to recognize their work as activists and healers and reinstate a connection to this kind of ancestral magic. Keeping her at a distance maintains a suppression of her knowledge, makes her an unruly haint. What do we lose by ignoring the old woman, by pushing away her witchiness (read: freedom-fighter, pride, strength, agency) when so much can be learned from her presence? I am interested in shifting the appearance and position of hags to consider how this presence leads to reimagining and restoring ancestral connections.

The hag and pervading antebellum stereotype of Mammy are similar figures created to produce a caricature whose difference determines palatability. The hag as old, ugly, and witchy plays into her banishment and isolation and contributes to an air of discontent and deceit. Mammy is also depicted in these terms, a description tied to her Blackness and lack of desirability. But her myth brings comfort instead of threat, as does her assumed contentment with circumstance. Her nurturing and devotional servitude almost grants her a position on the inside: she is loyal and potentially trustworthy. A keeper of children though never her own, Mammy is evocative of the hag, a negativemother or a mother who is lost. In some tales, the hag's banishment is contingent on loss: she loses her spouse, her children, and thus rights to property and personhood. As an absent-presence to her own family, Mammy also lacks what the hag does. Mammy no longer needed is a hag vanished, a distorted voice unheard beyond ostensibly sinister mutters. These myths produce maligned images of the Black women they represent: one a soft-bodied giver not afforded agency to take care of her own, another denied tenderness and desire beyond the form of "taking" blood, breath, or children. It is important to see that hags, witches, and mammies are more complex than popularly imagined. Remember, in reality, "domestic servants often were not grandmotherly types but teenagers or very young women. It was white supremacist imaginations that remembered these powerless, coerced slave girls as soothing, comfortable, consenting women" (Harris-Perry 2011, 72). Perversions of such realities lead to the kind of ghostliness the haint represents: redacted or embellished, but never fully seen.

In the spirit of "Mammy's revenge," let us shift the conditions of this banishment, not just as being put out, but as marronage, escape, a refusal or rejection of "the rules," a refusal to stay/play "dead." ${ }^{2}$ Hidden away (in the woods, in the house) suggests 
that what she knows must be kept out of sight lest we discover alternate ways of being and believing. In investigating the hag, I aim to reconceive her agency and complexity compromised by narratives that deem otherwise. Repositioning the hag allows for new perceptions on her shapes and movement and leads me to believe the hag is ancestral, a foremother who has lost what she means to keep. She will wait endlessly, or come back repeatedly with a vengeance, to make herself known.

\section{Outraged Foremamas}

Say a hag slips her skin for the sake of assimilation, puts on a face presumed more acceptable for survival, comes to tell us about ourselves, about herself. Say there is something in the blood, the letting and the sharing that brings us closer to meaning. The hag may be visiting, not victimizing, she may appear as a spirit when flesh will not suffice. Venetria K. Patton asserts "that ancestral bonds extend beyond the grave in order to maintain a sense of health and well-being in the face of a legacy of slavery and racial discrimination. . . the end of the physical body does not mean the end of one's connection to the community-communication continues through such things as dreams and visions" (Patton 2013, 55). Likewise, as Karla Holloway posits, "sometimes the presence can be mediative and instructive, sometimes it is mediative and condemnatory, sometimes it is mediative and silent. . . the ancestral presence constitutes the posture of (re)membrance. She is the linking of gender and culture" (Holloway 1991, 26). The ancestral presence is not always benevolent. and at times visitations are signs of warnings and wariness. Regardless, they haunt; their experiences, their suffering, their wants leave imprints. And our survival is interconnected. Such is the case of the character Lizzie in Phyllis Alesia Perry's Stigmata, who is left to bear the literal wounds of her ancestors after their visitations. The stigmata Lizzie experiences is not caused by an intention to bring harm, but to bring memory. Despite these painful and traumatic experiences, Lizzie also receives a tremendous amount of love and insight about her foremothers' experiences that help her reconstruct and preserve family histories and reshape her personal and familial futures (Perry 1998).

The hag as ancestral foremama resonates with Joanne Braxton's notion of "the outraged mother" who "embodies the values of sacrifice, nurturance, and personal courage-values necessary to an endangered group. . . Implied in all her actions and fueling her heroic ones is outrage at the abuse of her people and her person. She feels very keenly every wrong done her children, even to the furthest generations" (Braxton 1990, 2). Her visitations suggest that she is returning to what was taken from her, that which was hers and never hers. This is quite significant when considering conditions of enslaved mothers. In "Mama's Baby, Papa's Maybe: An American Grammar Book," Hortense Spillers argues that "under the conditions of captivity, the offspring of the female does not 'belong' to the Mother, nor is s/he 'related' to the 'owner,' though the latter 'possesses' it" (Spillers 2003b, 74). Regardless of whether the master "fathers" the child, the child is property before person, and the determination of whether s/he will be kept or sold is not so much determined by relation as it is by ownership. This must also be considered with the image of the hag/mammy: while she soothes one child her own may be taken. Because the child does not "belong" to the mother, all that s/he inherits is the mother's condition: slavery, kinlessness, ghostliness. The ancestral presence works to subvert this narrative by restoring a connection, by making one confront the outrage of what is missing, what is needed. She may be a protective and benevolent force that holds a message close to the ear, but she also holds the 
capacity to be unruly and intrusive. Viewing the hag as a presence to learn from and listen to instead of something to fear and leave behind shows that her haunting is not meant to take from us but to bring us closer to home, to knowing and remembering. This may be what she wants from us; it may also be what we need for ourselves.

\section{Recognizing Hag/ar}

I turn to this haint because even her name evokes the very figure I aim to explore. She is one of the most referenced metaphorical, ancestral figures used to describe the conditions of enslaved Black women and succeeding generations. Hagar was an enslaved Egyptian woman in the book of Genesis. Hagar is a relatable trope because of her suffering as raced, gendered, and owned. When her mistress Sarah (Sarai) grows impatient and weary of not being able to conceive children, Hagar is given to her master Abraham (Abram) to do her bidding and bear a child. Hers is a surrogate womb; the child she bears will not belong to her but instead to her masters. During Hagar's pregnancy, Sarah treats her cruelly out of disgust with what she views as Hagar's defiance. This leads Hagar to run to the desert where she is visited by God who convinces her to return. After she births a son, she continues to experience conflict and abuse. Sarah eventually has a son as well and, afraid the child Hagar bore will be an heir before her own, banishes her servant and the child she bore. Again, Hagar is in the wilderness, left with a skin of water, a little bread, and a child; she calls the ineffable name of God, who finds her and ensures she will be blessed (Genesis 16:1-16; 21:9-21). Hagar both believes in and is a haint. She shows us that the hag resonates with a spiritual presence, something personal and divine that does not rely on master narratives.

Hagar's perils and triumphs have often been used as a trope to understand histories of exploitation of Black women, most notably by Delores Williams, who views Hagar through a lens of African American womanist theology. Williams argues:

1) She's the first female in the Bible to liberate herself from the bonds of slavery. (She runs away from Abram and Sarai and heads back to Africa)

2) She's the only woman in the biblical text to name God... (Williams 1993)

Rather than name the god of her owners, Hagar relies on her own traditions and calls El Roi "the God who sees" (Genesis 16:13). Adam Clark furthers this by noting that Hagar's African heritage is central to an expanded interpretation of her narrative of liberation and her reclamation of the divine feminine (Clark 2012, 63). ${ }^{3}$ Like Mammy, Hagar is used to fulfill another's desires while discouraged from holding her own. However, as with all hags, there is more to name and see than we first perceive. Her "defiance" of her mistress is more akin to self-definition, an assertion of power in an ostensibly powerless situation. The turn to her own strategies (language, belief, traditions) is an act of agency and reclamation. By naming God, Hagar in turn names herself. It is this divine presence that provides tools for survival and ultimately leads to liberation. If we hold this biblical allegory in the same space as myths of mammies and witches, therein lies potential for revision and examining the ghostliness of Black women, another way of understanding haunting conditions. The hag is more than miserly and destitute, more than dimpled-smile servitude, neglectful mother, or compliant concubine. She may be outraged and outrageous, relentlessly prying us from sleep, but we must wake up, and as Clifton contends, respond to the call. The hag is powerful, but also at times lost to us. Hagar brings into focus an authority of 
betweenness, an assertion of personhood and will. She is attuned to her needs, her heritage, and inherited resources.

The Girl With the Ship on Her Head

Why did they give her that name?

Was it a nice day?

Does it matter?

It was not natural. And she was the first. -June Jordan, "The Difficult Miracle of Black Poetry in America"

Phillis Wheatley is so often beginning, so often "the first," but in this journey she is the end. The end, however, is not ever the end; it will come again, it has come before; such is the circuitous nature of haunting. Then and now, and evermore. It is important that we go back to move forward, ${ }^{4}$ that we fetch what we need to remember and move through: the poet Phillis Wheatley. Phillis is indeed a hag-an ancestral presence for Black women. Like Mammy, she is at times viewed through a narrow lens of subservience, though her enslaved position almost certainly ensures this. But, like Hagar, though she "performs" her master's desires, she is diligent in exercising her own. Wheatley's brief life between property and personhood, as poet and haunting foremother, places her in the space of the hag. The girl who would be bought and renamed Phillis Wheatley was born in or around 1753, forcibly crossed the Atlantic in 1761, and was delivered to Boston, Massachusetts, a state immersed in "family slavery" where enslaved Africans were both property and persons with limited rights and precarious situations. There, she was purchased by John and Susanna Wheatley. Though our access to histories of enslaved children aboard slave ships is limited, they were captured with or without their parents, and embarked on a perilous journey. Some sickened and died, or went overboard, out of indignation or the crew's desire to collect insurance. Others were brutalized and killed, and some survived. No one aboard was immune to horrors at sea, or to the physical and psychological terrors that marked and continue to haunt their bodies. If we consider bodies in transit, bodies of water, bodies of ships, and those captive African bodies, then we must also consider all that the body holds and what the flesh bears "as a primary narrative... its seared, divided, ripped-apartness, riveted to the ship's hole, fallen, or 'escaped' overboard" (Spillers 2003b, 206). Haints are evidence of atrocity. This transatlantic crossing from human to seared flesh and water-beaten ghost leaves the child an open wound, an aperture through which both human and nonhuman traverse.

Upon landing in the blistering July heat of Boston, perhaps the girl believed outside of dry-mouth and dream she could be "free" of the ship. Though she was called (and eventually called herself) many things, refuse of little value after reaching land, when purchased by John and Susannah Wheatley she is called Phillis, after the ship that brought her. But why, as June Jordan inquires, "why did they give her that name" (Jordan 1986, 253)? I am compelled by this ghost. This literal and figurative demarcation of bondage suggests she remains, even after landing, a girl with a ship on her head. What does it mean to carry such a thing? As Christina Sharpe queries, "is Ship a signifier of the im/possibility of Black life. . a reminder and/or remainder of the Middle Passage, of the difference between life and death?" (Sharpe 2016, 6). There is nothing proper about this naming. Phillis Wheatley is bound by name perpetually rowing a diasporic River Styx. No matter how carefully the word is written, how gently the 
Wheatleys may have spoken, this name facilitates her haintliness. How should a girl with a ship on her head survive to be anything more than transport for rum and grief? How to become human again?

Phillis Wheatley, named for one vessel, serves as another through which her masters expressed their faith and promise, and mourned their own losses: Phillis, a surrogate for a favored child lost years before. As biographer Vincent Carretta notes, "Just a few weeks before the Wheatleys' purchased Phillis they had observed the ninth anniversary of the death of their daughter Sarah" (Carretta 2011, 14). Phillis is purchased at almost the exact age of the Wheatley child when she died. She is a sable substitute for what was missing, though her enslaved position does not allow her to fully step into the role of daughter. Despite the Wheatleys' misnaming, their generosity and religious obligation lead them to educate the slave-girl; it is Phillis who comes to name herself a poet, claiming her "intrinsic ardour" alongside spirits that will her ink. ${ }^{5}$ Through the language she is afforded, she maintains cultural connections to ancestral and spiritual forces and thus a power of reclamation. Phillis pushes back on the confines of her enslavement to rely on hags for preservation. Like Hagar, she is called one thing, and in defiance (which is really an insistence on being alive) names herself (and God no doubt), another: Phillis rebirthed as property and prodigy, "daughter," foremother lost who is never quite well. When owned by the Wheatleys she is given a platform for her work, able to publicly profess. In freedom she is left indigent, displaced, and largely unpublished, and still, persistent on being. Phillis, an exiled hag, dies alone at thirty-one, buried somewhere questionable and unmarked.

\section{Mercy in the Water: Inheriting the Hag}

Begin again. Here, which is not the beginning but a point of rupture and return. Middle of the Atlantic, Middle Passage, a space between shores, between ripple and sea-bottom, flight and capture. I revisit this space to name the hag that came before-the one present for Phillis in the Middle Passage. This final voyage into shadow and dim ends by returning "home" - to water, to the hag as inherited and sacred, to bring out the girl who would become Phillis Wheatley's unwavering subjectivity, and the hag who helps her survive. This presence is most salient for me in what is perhaps Phillis Wheatley's most anthologized poem, "On Being Brought from Africa to America." As we wade in these waters, I pose that the hag in this poem can be found in "mercy," and position mercy as the Yoruba orisha Yemoja.

\section{On Being Brought from Africa to America}

'Twas mercy brought me from my Pagan land,

Taught my benighted soul to understand

That there's a God, that there's a Saviour too:

Once I redemption neither sought nor knew.

Some view our sable race with scornful eye,

"Their colour is a diabolic die."

Remember Christians, Negroes, black as Cain,

May be refin'd and join th' angelic train. (Wheatley 2001, 40)

Written by a fourteen-year-old Phillis, on its surface the poem appears more a praise song of conversion or rescue. It seems to move linearly, fully, from Africa to America, 
but water licks back at itself to remember, and the poem moves accordingly. The title signifies this, "being brought" is not about a fixed location, but instead a reflection on transport and the transition from human to slave and sinner. It is about what happens on the course of the current and what else is there. Spatially, we are placed in the Atlantic coming from Africa, going to America, onboard a namesake, a vessel with its own rules and regulations. This alters the possibilities of "Pagan land," relegating "land" to the floating world of the slave ship. For Africans packed and spooned, adorned in chains, is this not a place of heathenish filth, a pagan land? But there is "mercy," "Twas mercy brought me from my Pagan land" (line 1). And it is mercy I claim as the hag. I frame this interpretation by first recognizing mercy as a spectral presence in this poem. Surely the Middle Passage is a space full of ghosts, the Atlantic a watery grave teeming with "sixty million and more." ${ }^{6}$ The echo of cracked-lip prayers, the spirits that respond. Mercy seems personified, ${ }^{7}$ a saving grace in a passage of catastrophe, and this is what raises my brow throughout the poem. I view Mercy as a kind "holy ghost" that propels the piece and brings across a toothless child who should never have been aboard the schooner Phillis. ${ }^{8}$ Mercy imparts understanding. Mercy teaches new words for a new world, teaches the speaker to see double. Mercy comforts through a perilous voyage. Mercy empowers. Perhaps "On Being Brought from Africa to America" is a poem of praise, but I do not believe the gratitude is for Christianity, or for the Wheatleys. I believe it is for Mercy.

To go here, we must be willing to view Phillis outside the context of Christianity and consider that upon being brought, the girl was not a blank slate devoid of her own cultural practices and traditions. As a Middle Passage survivor, the girl evokes what Bassard refers to as a language of African survivorship that "calls to mind the survival of Africanity and African structures within New World spaces" and concerns "the issue of ancestors and remembrance ... the survival of black texts despite centuries of neglect and hostility" (Bassard 1999, 36). Interpreting her poems through this framework lets us see more than a girl with a ship on her head. It creates an opening to understand that Phillis, like so many of those who crossed before and after her, held spiritual beliefs that were embedded in their everyday lives, that survived despite trans-Atlantic crossing. Likewise, this makes it possible to recognize that Phillis knew another kind of Mercy.

In this reading of the poem I am offering that Mercy is the orisha Yemoja. Orisha are not idly worshiped gods, they are multifaceted ancestral and spiritual energies that ritually commune with their human children. Honored throughout the diaspora, woven into the quotidian, they are evidence of the integration of worlds of the living, the dead, and the spirit, evidence that despite manipulation of language and appearances, beneath Mercy, there is another text, another language inscribed in the body (of the poem, of the poet) that persevered. African diasporic traditions and practice continued in the "New World" regardless of capture and conversion. Orisha were hidden from plain view, integrated into acceptable practices, or given new names. As Teresa Washington explains, "when enslaved Africans were forced to adopt Catholicism, they hid the Orisà behind or inside of the empty figurines of saints, and Yemoja found a perfect hiding place within the Virgin Mary with whom she is still associated in such syncretic religions as Santeria, Lucumí... Candomblé and Umbanda" (Washington 2013, 245). I contend that for Yemoja to be "within" Mercy is not so much farfetched as it is a strategy of survival, a means of remembering.

Yemoja's name translates as "mother of fish," but across the African diaspora she is viewed as many things: mother of orisha, of waters and fluid, blood and tears, semen, 
and afterbirth. Mother of life. And, primarily because of the crossing, she is called mother of ocean and salt water. As Washington contends, "Yemoja did not just help enslaved Africans survive the Middle Passage; she was there" (222). In those roaring waters Yemoja is called out in the confines of slaver hulls, danced for, and saluted on decks. It is Yemoja who also fights to survive and be remembered. In the Middle Passage, it was Yemoja's stomach sliced through by slaveships, her arms leapt or thrown into, she who became home away from home. As ocean she is a paradox, holding life and unimaginable possibility in her hands while death gathers in the hem of her skirts. But, even as tomb, Yemoja is always womb, nurturing bones like a fetus in amniotic fluid, strengthening the waters' power. She is a force to be reckoned with, who can "do and undo, [who] can devastate and deliver the devastated" (219). Yemoja is a divine protector, a geographical and spiritual bridge from one world to another, between life and death, life and afterlife. As Mercy, it is Yemoja who brings the girl from Africa to America, and it is on her back that the child is transformed from subject to object. As Mercy, Yemoja is a mirror that reflects the speaker's "benighted soul"-not with ignorance but Blackness. She teaches the girl to remember herself, not as "diabolic die" but as "refin'd" and as a reflection of the divine. And it is this Mercy that seems to have been there all along, waiting, as some hags do, to be taken in. Arms stretched across the Atlantic, thighs rubbing through the Charles River and Mississippi, Yemoja opens a fist in Boston Harbor. The ocean is full of ghosts and black fishes, and Yemoja is mama of the sea, surge and swell and gentle wave-suck, salt spittle-kiss. Yemoja, whose waves cradle and crush, Yemoja who resides in Mercy, who holds all things, blood and pus, tears and shit, and spit, Yemoja in the sweet and souring mother's milk. Yemoja, mother of all life, of the drowned and dying, whose children are never alone. It is Yemoja who "holds the crown, having enabled the Crossing" (Alexander 2006, 329). How miraculous. How merciful.

Perhaps we can place Phillis's mother in this merciful space as well. It is unknown if the girl was captured with her, if she was aboard the schooner Phillis, sold elsewhere or was one of the twenty-five who did not survive. She is, however, the only documented snatch of the girl's memory that has been recounted. The nineteenth-century "memoir" by distant Wheatley relative Margaretta Odell $(1834)^{9}$ suggests Phillis retained little memory of her childhood, "excepting the simple circumstance that her mother poured out water before the sun at his rising-in reference no doubt to an ancient African custom" (Wheatley 2001, 82). Odell's notion that the poet preserved little memory is complicated by the girl's immersion in an institution that aimed for her to forget. This image of mama and ritual is a loaded one and may also be a representation of what is prominent in the girl's memory, mother and water. And "water overflows with memory. Emotional memory. Bodily memory. Sacred memory" (Alexander 2006, 290). The Middle Passage is a nexus of these elements, where mother speaks to a larger understanding of mother-loss and extended kin, mothers out of necessity, and all flesh leads back to the haint in need of remembering-yeye, mother of spirits, mother over water, in water, of water, and positions the hag as a spiritual presence. Mercy, this hag who "brings knowledge from past, present, and future to a particular moment called now. Time becomes a moment, an instant. .." (329), as in the line, "once redemption I neither sought nor knew" (line 4). Once I was not a slave, once I was not a sinner, once I did not need to apologize for myself. And, as Jordan exclaims, "once I existed beyond and without these terms under consideration" (Jordan 1986, 255). Once I existed beyond these terms, this time, this place, and I still do. In "On Being Brought from Africa to America," it is not redemption that is essential, but 
reclamation of individual and collective subjectivity. Phillis calls out "some" and "Christians" "our sable race" and "Negroes" "Remember, Christians, Negroes, black as Cain, /May be refin'd and join th' angelic train" (lines 7-8). A shift occurs from this is what $I$ remember to this is what they must remember. And they must remember us. I read: remember Christians-converters, captains, trappers, owners; remember Negroes - these bodies, marked by Blackness, marked by death, made ghostly by crossing. Remember these bodies, "may be refin'd" (line 8), may already be saved, and "join the angelic train" (line 8 ), the ancestors, the divine, a train of remembrance, marked by mama brought by Mercy. This spiritual presence and assertion of self-affirmation allow her to disrupt a systematic force of demise and position the hag as an active agent in her quest for personhood and redemption. It is the hag Phillis calls on during crossing, a hag who calls her name, and through the poem she responds.

How does it feel to live with ghosts, to be a haint beneath the veil, forever in shadow? What does it look like to rectify a problem, to know that problem is not Blackness but instead something other, that in the attempt to destroy and define, has rendered it ghostly? I have worked to show you, and what I aimed to reveal about haunting is manifold. The first is that as a state of betweenness, haunting allows for multiple ways of seeing and navigating. It is both injury and a possibility for salve and recovery, a pathway to knowledge and recovery of Black women's subjectivities. Second, that in our liminal state of personhood, black women are haints, passageways between here and there, life and death, a bridge to our own freedom. Finally, I explore a lineage of hags, a primary manifestation of the haint, dismantling maligning images to show hags as an ancestral and spiritual presence that demands recognition and embrace, not excision. Through the figure of the hag, I work to show the literary as a means through which Black women confront socially prescribed myths to conjure those of our own making and cultural heritage in order to sustain survival. In this essay I speak alongside Lorde's argument that "poetry is not a luxury," it is illumination and possibility. And, in the strange case of living with and as ghosts, "it is a vital necessity of our existence" (Lorde 1984, 25). In empowering us to touch what is deep, hidden, and ancient, the poem is a space for theorizing lived experience and a means of textual mediumship, the poem a conduit through which ghosts bring forth their desires. In my effort to refigure the hag I use the poems of Lucille Clifton and Phillis Wheatley to enforce underlying messages of mercy and the survival of an ancestral presence, the complexity of inheritance, and the innumerable ways haunting influences Black women's lives. These poems permit hags to speak; they are an opening to remembrance and revival. Black women's haintly inheritance is both demonized and deified. We inherit the mark of the veil, the ghostly blur of shadows, but also a deep connection with something sacred and invaluable that calls for a reckoning. It is in this insistence on being seen and heard that hags reveal themselves, wise and wondrous, ancestral, and outrageously divine.

\section{Notes}

1 In The Collected Poems of Lucille Clifton 1965-2010 (Clifton 2012), the page breaks after line 28, "in the shadow of your room." Instead of feeling interrupted, the turn of the page feels instead like the reader is doing as instructed "waiting" for further directions.

2 Orlando Patterson's theories of social death argue that enslavement relegated Black people to the Western space of the dead. Having no claim to person or property, "a genealogical isolate" extended social value only in relation to one's master (Patterson 1982). This is also a nod to Sharon Holland's Raising the 
Dead, which begs the question "what if some subjects never achieve, in the eyes of others, the status of 'the living"'? (Holland 2000).

3 To explore the divine feminine, Clark furthers Williams's observation of the Egyptian god $\mathrm{Ra}$ as $\mathrm{El}$ Roi, and notes that it is the female goddesses Hathor and Maat who serve as his eyes. Thus, in calling on El Roi, Hagar is actually calling on the sight of Hathor and Maat, divine feminine energies.

4 "Sankofa" in Twi, a Ghanaian language, translates as "go back and get it," suggesting that we cannot continue without carrying what we need with us from the past. As an Adinkra symbol, the most "popular" image is that of a bird, feet facing forward, neck craning back, an egg in its mouth. This characterization raises the question I am working through in the last section of the essay: what does it look like to carry the spirit(s) of the past into our present, in order to birth a future?

5 The opening lines of Wheatley's poem "To the University of Cambridge, In New England" state: "While an intrinsic ardour prompts to write, / the Muses promise to assist my pen."

6 Toni Morrison dedicates her novel Beloved to the sixty million and more, an estimated number referencing those Africans who were fatal victims of slavery (who did not survive captivity in dungeons, who did not survive Middle passage, who did not make it or survive long in "new worlds.")

7 From this point on I capitalize Mercy to signify the shift from abstract to proper noun. In this regard I am furthering my argument that Mercy is the named hag in Wheatley's poem. It is this holy ghost called Mercy that I aim to align with Yemoja.

8 In a 1761 letter from Timothy Fitch (the owner of the schooner Phillis) to its captain Peter Gwinn, Fitch explicitly writes not to bring women and girls.

9 Odell's memoir is included in Wheatley 2001.

\section{References}

Alexander M. Jacqui. 2006. Pedagogies of the sacred. In Pedagogies of crossing: Meditations on feminism, sexual politics, memory, and the sacred. Durham, N.C., and London: Duke University Press.

Bassard, Katherine Clay. 1999. Spiritual interrogations: Culture, gender, and community in early African American women's writing. Princeton: Princeton University Press.

Braxton, Joanne M. 1990. The outraged mother. The Scholar \& Feminist XXX: Past controversies, present challenges, future feminisms 3 (3) and 4 (1). https://cdn.atria.nl/ezines/web/S\&FOnline/2007/No2+3/barnard/braxton.pdf.

Brooks, Kinitra D. 2018. Searching for Sycorax: Black women's hauntings of contemporary horror. New Brunswick, N.J.: Rutgers University Press.

Carretta, Vincent. 2011. Phillis Wheatley: Biography of a genius in bondage. Athens: University of Georgia. Christian, Barbara. 1987. The race for theory. Cultural Critique 6: 51-63.

Clark, Adam. 2012. Hagar the Egyptian: A womanist dialogue. Western Journal of Black Studies 36 (1): 48-56.

Clifton, Lucille. 2012. "shadows." In The collected poems of Lucille Clifton 1965-2010, ed. Kevin Young and Michael S. Glaser. Rochester, N.Y.: BOA Editions.

Davis, Jordan. 2013. Unsparing truths: On Lucille Clifton. The Nation, June 29. https://www.thenation.com/ article/archive/unsparing-truths-lucille-clifton/.

$\mathrm{Du}$ Bois, W. E. B. 1903. The souls of black folk: Essays and sketches. Chicago: A. C. McClurg \& Co.

Gordon, Avery. 1997. Ghostly matters: Haunting and the sociological imagination. Minneapolis: University of Minnesota Press.

Harris-Perry, Melissa V. 2011. Sister citizen: Shame, stereotypes, and black women in America. New Haven, Conn.: Yale University Press.

Henderson, Mae. 2014. Speaking in tongues and dancing diaspora: Black women writing and performing. Oxford: Oxford University Press.

Holland, Sharon Patricia. 2000. Raising the dead: Readings of death and (black) subjectivity. Durham, N.C.: Duke University Press.

Holloway, Karla F. C. 1991. Moorings and metaphors: Figures of culture and gender in black women's literature. New Brunswick, N.J.: Rutgers University Press.

Jordan, June. 1986. The difficult miracle of black poetry in America or something like a sonnet for Phillis Wheatley. Massachusetts Review 27 (2): 252-62.

Lorde, Audre. 1984. Sister outsider: Essays and speeches. Trumansburg, N.Y.: Crossing Press. 
Lupton, Mary Jane. 2006. Lucille Clifton: Her life and letters. Westport, C.T: Praeger.

Morrison, Toni. 1989. Unspeakable things unspoken: The Afro-American presence in American literature. Michigan Quarterly Review 28 (1): 1-34.

Online Etymology Dictionary. n.d. s.v. "Haunt." https://www.etymonline.com/search?q=haunt\&ref= searchbar_searchhint.

Parham, Marisa. 2008. Haunting and displacement in African American literature and culture. New York: Routledge.

Patterson, Orlando. 1982. Slavery and social death: A comparative study. Cambridge, Mass: Harvard University Press.

Patton, Venetria K. 2013. The grasp that reaches beyond the grave: The ancestral call in black women's texts. Albany: SUNY Press.

Perry, Phyllis Alesia. 1998. Stigmata. New York: Hachette.

Pulliam, June Michele, and Anthony J. Fonseca. 2016. Ghosts in popular culture and legend. Santa Barbara, Calif.: Greenwood Press.

Redding, Arthur. 2001. Haints: American ghosts, ethnic memory, and contemporary fiction. Mosaic: An Interdisciplinary Critical Journal 34 (4): 163-82.

Ross, Joe. 1980. Hags out of their skins. Journal of American Folklore 93 (368): 183-86.

Ryan, Judylyn S. 2005. Spirituality as ideology in black women's film and literature. Charlottesville: University of Virginia Press.

Sharpe, Christina. 2016. In the wake: On blackness and being. Durham, N.C.: Duke University Press.

Spillers, Hortense. 2003a. Interstices: A small drama of words. In Black, white, and in color: Essays on American literature and culture. Chicago: University of Chicago Press.

Spillers, Hortense. 2003b. Mama’s baby, papa's maybe. In Black, white, and in color: Essays on American literature and culture. Chicago: University of Chicago Press.

Take me to the water. n.d. Hymnary.org. https://hymnary.org/text/take_me_to_the_water.

Teish, Luisah. 1985. Jambalaya: The natural woman's book of personal charms and practical rituals. San Francisco: Harper \& Row.

Wade in the water. n.d. Negrospirituals.com. http://www.negrospirituals.com/songs/wade_in_the_water. htm.

Washington, Teresa. 2013. The sea never dies. In Yemoja: Gender, sexuality, and creativity in the Latina/o and Afro-Atlantic diasporas, ed. Solimar Otero and Toyin Falola. Albany: State University of New York Press.

Wheatley, Phillis. 2001. Complete writings. Introduction by Vincent Carretta. New York: Penguin Books. Williams, Delores. 1993. Sisters in the wilderness: The challenges of womanist God-talk. Maryknoll, N.Y.: Orbis Books.

Young, Hershini Bhana. 2006. Haunting capital: Memory, text and the black diasporic body. Hanover, N.H.: Dartmouth College Press.

drea brown is a poet-scholar and Assistant Professor in the Department of English at Texas State University. drea is the author of dear girl: a reckoning, winner of the 2014 Gold Line Press chapbook contest, and co-editor of Teaching Black: The Craft of Teaching on Black Life and Literature (Nov 2021). A Hedgebrook, Cave Canem, and VONA alum, drea's writing has also appeared in journals and anthologies such as Smithsonian Magazine, Southern Indiana Review, Zócalo Public Square, and Stand Our Ground: Poems for Trayvon Martin and Marissa Alexander. drea.brown@txstate.edu

Cite this article: brown d (2021). Conjuring the Ghost: A Call and Response to Haints. Hypatia 36, 485-502. https://doi.org/10.1017/hyp.2021.41 